\title{
Loktanella salsilacus gen. nov., sp. nov., Loktanella fryxellensis sp. nov. and Loktanella vestfoldensis sp. nov., new members of the Rhodobacter group, isolated from microbial mats in Antarctic lakes
}

Correspondence

Stefanie Van Trappen stefanie.vantrappen@UGent.be

\author{
Stefanie Van Trappen, Joris Mergaert and Jean Swings
}

Laboratorium voor Microbiologie, Vakgroep Biochemie, Fysiologie en Microbiologie, Universiteit Gent, K. L. Ledeganckstraat 35, B-9000 Gent, Belgium

\begin{abstract}
A taxonomic study was performed on 26 strains isolated from microbial mats in Antarctic lakes of the Vestfold Hills and the McMurdo Dry Valleys. Phylogenetic analysis based on 16S rRNA gene sequences placed these strains within the Rhodobacter group of the $\alpha$-subclass of the Proteobacteria. Sequence similarity values for the strains with their nearest phylogenetic neighbours (Jannaschia, Octadecabacter and Ketogulonicigenium) ranged between $94 \cdot 0$ and 95.8\%. DNA-DNA hybridizations and comparison of repetitive extragenic palindromic DNA-PCR (rep-PCR) fingerprinting patterns revealed that these strains are members of three distinct species. The isolates are Gram-negative, chemoheterotrophic, non-motile rods and their DNA G + C contents range from 59.4 to $66.4 \mathrm{~mol} \%$. Whole-cell fatty acid profiles are similar and the primary fatty acid in all the strains is $18: 1 \omega 7 c(74 \cdot 1-87 \cdot 7 \%$ of total). Genotypic results together with phenotypic characteristics allowed the differentiation of these species from related recognized species of the $\alpha$-Proteobacteria and the strains are assigned to a new genus, Loktanella gen. nov., with three novel species: Loktanella salsilacus sp. nov. (type species), consisting of ten strains with LMG $21507^{\top}$ (= CIP $108322^{\top}$ ) as type strain; Loktanella fryxellensis sp. nov., consisting of 12 strains with LMG $22007^{\top}\left(=\mathrm{CIP} 108323^{\top}\right)$ as type strain; and Loktanella vestfoldensis sp. nov., consisting of four strains with LMG $22003^{\top}\left(=\mathrm{CIP} 108321^{\top}\right)$ as type strain.
\end{abstract}

During the last few years, there has been an increase in the isolation and description of novel marine and freshwater bacteria and several of these novel isolates represent members of the $\alpha$-subclass of the Proteobacteria, in which they are phylogenetically related to the genus Rhodobacter. The abundance of some members from the Rhodobacter group in these aquatic environments has been correlated with the presence of algal blooms and it has been suggested that they play an important role in sulfur cycling (González et al., 1999, 2000).

Several of these novel members originate from Antarctic habitats: Antarctobacter heliothermus (Labrenz et al., 1998),

Published online ahead of print on 23 January 2004 as DOI 10.1099/ ijs.0.3006-0.

\footnotetext{
Abbreviation: rep-PCR, repetitive extragenic palindromic DNA-PCR.

The GenBank/EMBL/DDBJ accession numbers for the 16S rRNA gene sequences of strains LMG $22007^{\top}$, LMG $22003^{\top}$, LMG $21507^{\top}$, LMG 22000, LMG 22002 and LMG 22006 are AJ582225, AJ582226, AJ440997, AJ582228, AJ582229 and AJ582227, respectively.

Normalized rep-PCR profiles and a dendrogram are available as supplementary material in IJSEM Online.
}

Roseovarius tolerans (Labrenz et al., 1999), Staleya guttiformis and Sulfitobacter brevis (Labrenz et al., 2000) from Ekho Lake, and Octadecabacter arcticus and Octadecabacter antarcticus (Gosink et al., 1997) from polar sea ice and sea water. Recently, two new genera have been added to this Rhodobacter group: Ketogulonicigenium (Urbance et al., 2001), isolated from soil and which oxidizes L-sorbose to 2-keto-L-gulonic acid, and Jannaschia helgolandensis (Wagner-Döbler et al., 2003), isolated from the North Sea.

During the MICROMAT project (November 1998 to February 2001), 746 heterotrophic bacterial strains were isolated from microbial mat samples, collected from ten Antarctic lakes (Van Trappen et al., 2002). Numerical analysis of the fatty acid composition of the isolates revealed 41 clusters, and 16S rRNA gene sequence analysis, performed on representative strains, showed that they belong to the $\alpha-, \beta$ - and $\gamma$-subclasses of the Proteobacteria, the Gram-positives and the Bacteroidetes (Van Trappen et al., 2002). Fatty acid analysis and $16 \mathrm{~S}$ rRNA gene sequence analysis showed that diversity of heterotrophic bacteria in microbial mats from Antarctic lakes is very high. Moreover, many fatty acid clusters were shown to contain multiple taxa when tested by repetitive extragenic palindromic DNA-PCR 
(rep-PCR) fingerprinting, a technique used to investigate the genomic diversity of each fatty acid cluster in greater detail, especially those belonging to the Bacteroidetes group (Van Trappen et al., 2003, 2004).

In the present work we studied the relationships of 26 strains from fatty acid cluster 41 (Van Trappen et al., 2002, belonging to the $\alpha$-Proteobacteria), using polyphasic taxonomic characterization.

The investigated isolates, their origin and genomic profile grouping are given in Table 1 . Strains were routinely cultivated on marine agar 2216 (Difco) at $25^{\circ} \mathrm{C}$ for $48 \mathrm{~h}$, except when indicated otherwise.

DNA was prepared according to the method of Pitcher et al. (1989). rep-PCR fingerprinting (based on primers targeting the repetitive extragenic palindromic sequence) was performed on all strains of fatty acid cluster 41 (59 strains) isolated by Van Trappen et al. (2002), using the primers GTG $_{5}$ and REP1R-I and REP2-I (Versalovic et al., 1991), as described by Rademaker \& de Bruijn (1997) and Rademaker et al. (2000). Numerical analysis was carried out using the BIONUMERICS software package (Applied Maths). Twentysix of these strains, listed in Table 1, could be divided into three different clusters according to their combined profile type (available as supplementary material in IJSEM Online) and these clusters were delineated by numerical analysis at a Pearson correlation coefficient level of $50 \%$. They are hereafter referred to as rep-PCR profile type I (comprising 12 strains), type II (four strains) and type III (ten strains). It is now well established that similar rep-PCR profiles are correlated to high total genomic DNA-DNA hybridization values (Versalovic et al., 1994; Rademaker \& De Bruijn, 1997; Rademaker et al., 2000; Van Trappen et al., 2003, 2004).

The almost-complete 16S rRNA gene sequences (1404$1449 \mathrm{nt})$ of strains LMG $22003^{\mathrm{T}}$, LMG 22006, LMG $22007^{\mathrm{T}}$, LMG $21507^{\mathrm{T}}$, LMG 22000 and LMG 22002 were determined as described previously (Van Trappen et al., 2004). The closest related sequences were found using the FASTA program and the sequences from reference strains were aligned, with editing of the alignment and reformatting performed with the BIOEDIT program (Hall, 1999) and FORCON (Raes \& Van de Peer, 1999). Evolutionary distances were calculated using the evolutionary model of Jukes and Cantor and a phylogenetic tree (shown in Fig. 1) was constructed using the neighbour-joining method (Saitou \& Nei, 1987) with the TREECON program (Van de Peer \& De Wachter, 1994). Dendrograms obtained by maximumparsimony and maximum-likelihood analyses showed essentially the same topography (data not shown).

The novel Antarctic strains form a distinct evolutionary clade, supported by high bootstrap values, within the $\alpha$-Proteobacteria and are associated with the Rhodobacter group. A phylogenetic tree showing the position of the strains to their closest neighbours is shown in Fig. 1.

The 16S rRNA gene sequence of strain LMG $22007^{\mathrm{T}}$ (representative for the strains of rep-PCR profile type I) revealed $98.6 \%$ similarity to that of strain LMG $21507^{\mathrm{T}}$ (identical to that of LMG 22000 and LMG 22002, and representative for rep-PCR profile type III) and $95 \cdot 4 \%$ to that of strain LMG $22003^{\mathrm{T}}$ (identical to that of strain LMG 22006, and representative for rep-PCR profile type II). The strains with nearest related sequences to that of strain LMG $22007^{\mathrm{T}}$ (rep-PCR profile I) were J. helgolandensis Hel $10^{\mathrm{T}}(95 \cdot 8 \%)$, O. antarcticus $307^{\mathrm{T}}(94.5 \%)$ and the currently unclassified marine alpha proteobacterium strain QSSC9-5 (97.3\%). The 16S rRNA gene sequence of strain LMG $22003^{\mathrm{T}}$ (rep-PCR profile type II) showed $95.4 \%$ sequence similarity to $\mathrm{J}$. helgolandensis $\mathrm{Hel} 10^{\mathrm{T}}$, $94 \cdot 2 \%$ to Ketogulonicigenium vulgare DSM $4025^{\mathrm{T}}, 94 \cdot 3 \%$ to Ruegeria algicola DSM $10251^{\mathrm{T}}$ and $96 \cdot 2 \%$ to the currently unclassified strain AS-26. The $16 \mathrm{~S}$ rRNA gene sequence of strain LMG $21507^{\mathrm{T}}$ (rep-PCR profile type III) showed $95 \cdot 7 \%$ similarity to $\mathrm{J}$. helgolandensis $\mathrm{Hel} 10^{\mathrm{T}}, 94 \cdot 2 \%$ to

Table 1. Strains investigated, source of isolation and rep-PCR profile type

LMG, BCCM/LMG Bacteria Collection, Laboratorium voor Microbiologie, Gent, Belgium; numbers prefixed 'R-' refer to the strain numbers as preserved in the research collection of the Laboratorium voor Microbiologie, Universiteit Gent, Belgium and as used by Van Trappen et al. (2002).

\begin{tabular}{|c|c|c|}
\hline Species (rep-PCR cluster) & Strain designations & Isolation site \\
\hline Loktanella fryxellensis (I) & $\begin{array}{l}\text { LMG } 22007^{\mathrm{T}}\left(=\mathrm{R}-7670^{\mathrm{T}}\right), \mathrm{LMG} 22008 \text { (=R-7672), LMG } 22009 \\
(=\mathrm{R}-7726), \mathrm{LMG} 22010 \text { (=R-7728), R-7601, R-7605, R-7671, } \\
\text { R-7729, R-7732, R-7735, R-8013, R-8014 }\end{array}$ & Lake Fryxell, Dry Valleys \\
\hline \multirow[t]{2}{*}{ Loktanella vestfoldensis (II) } & LMG $22003^{\mathrm{T}}\left(=\mathrm{R}-9477^{\mathrm{T}}\right)$, LMG $22006(=\mathrm{R}-9184)$ & Ace Lake, Vestfold Hills \\
\hline & LMG 22004 (=R-9054), LMG 22005 (=R-9057) & Pendant Lake, Vestfold Hills \\
\hline \multirow[t]{2}{*}{ Loktanella salsilacus (III) } & $\begin{array}{l}\text { LMG } 21507^{\mathrm{T}}\left(=\mathrm{R}-8904^{\mathrm{T}}\right), \mathrm{LMG} 21999 \text { (=R-8968), R-8884, } \\
\text { R-8901, R-9036 }\end{array}$ & Ace Lake, Vestfold Hills \\
\hline & $\begin{array}{l}\text { LMG } 22000 \text { (=R-9030), LMG } 22001 \text { (=R-9066), LMG } 22002 \\
(=\mathrm{R}-9068), \mathrm{R}-9064, \mathrm{R}-9186\end{array}$ & Organic Lake, Vestfold Hills \\
\hline
\end{tabular}




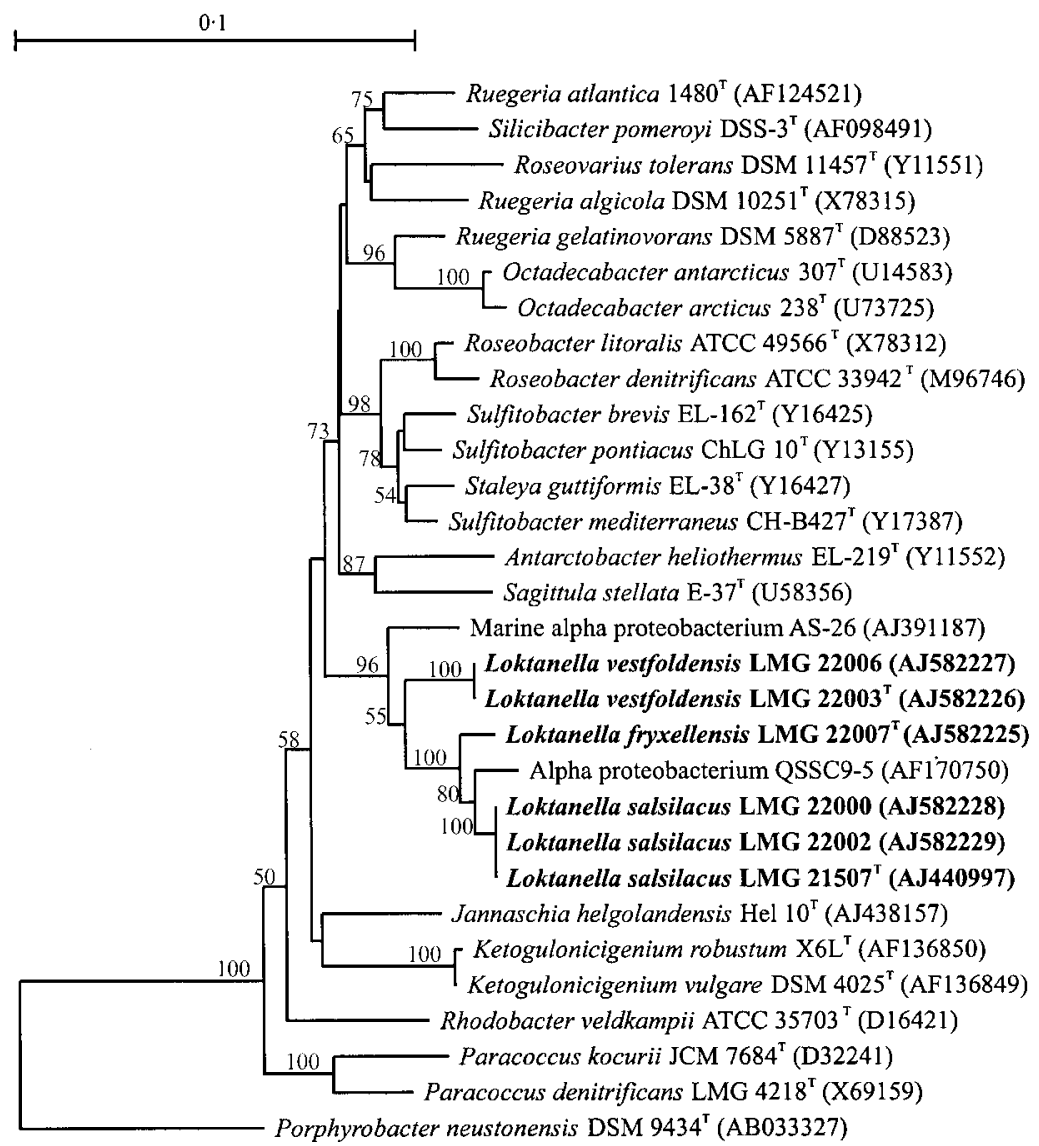

Fig. 1. Neighbour-joining dendrogram showing the estimated phylogenetic relationships of Loktanella salsilacus, Loktanella fryxellensis, Loktanella vestfoldensis and other related genera of the $\alpha$-Proteobacteria on the basis of $16 \mathrm{~S}$ rRNA gene sequences. Porphyrobacter neustonensis was chosen as outgroup. Bootstrap values are shown as percentages of 500 replicates, when more than $50 \%$. Bar, 1 nt substitution per 100 nt. The GenBank accession number for each reference strain is given in parentheses.
O. antarcticus $307^{\mathrm{T}}, 94 \cdot 2 \%$ to K. vulgare DSM $4025^{\mathrm{T}}$ and $98.4 \%$ to strain QSSC9. The low level of sequence similarities of the novel strains with recognized bacteria belonging to the Rhodobacter group of the $\alpha$-Proteobacteria $(91 \cdot 0-95 \cdot 8 \%)$ clearly demonstrates that they represent a new genus.

Genomic relatedness between the novel Antarctic strains, representing the three different rep-PCR profile types, was determined by DNA-DNA hybridizations. DNA was prepared according to the method of Marmur (1961) and DNA-DNA hybridizations were carried out with photobiotin-labelled probes in microplate wells as described by Ezaki et al. (1989), using an HTS7000 Bio Assay Reader (Perkin Elmer) for fluorescence measurements. Hybridization temperature was $45^{\circ} \mathrm{C}$ and reciprocal experiments were performed for every pair of strains. The mean hybridization level between strains LMG $22007^{\mathrm{T}}$ (rep-PCR profile type I), LMG $22003^{\mathrm{T}}$ (rep-PCR profile type II) and LMG $21507^{\mathrm{T}}$ (rep-PCR profile type III) ranged between $10 \cdot 5$ and $17 \cdot 6 \%$, indicating that the strains represent three different species (Wayne et al., 1987). Differences between reciprocal experiments were less than $10 \%$. The rep-PCR profiles within each of the clusters I and II were almost identical (see Table 1 and supplementary data in IJSEM Online), indicating that within each of these clusters strains represent a single species (Versalovic et al., 1994). Indeed, the 16S rRNA gene sequences of two strains from rep-PCR group II are identical. Hybridization values of the three representative strains (LMG $21507^{\mathrm{T}}$, LMG 22000 and LMG 22002) of rep-PCR profile type III were between $78 \cdot 2$ and $85.5 \%$, indicating that these strains represent a single new species, as would be expected from their identical 16S rRNA gene sequences.

The $\mathrm{G}+\mathrm{C}$ content of the DNA from the Antarctic strains was determined using an HPLC method, as described by Van Trappen et al. (2003). G+C values of strains LMG $22007^{\mathrm{T}}$, LMG 22008, LMG 22009 and LMG 22010 from repPCR cluster I are $65 \cdot 7,66 \cdot 2,66 \cdot 4$ and $66 \cdot 3 \mathrm{~mol} \%$, respectively; values for strains LMG $22003^{\mathrm{T}}$, LMG 22004 , LMG 22005 and LMG 22006 from rep-PCR cluster II are $62 \cdot 1,62 \cdot 6,62 \cdot 3$ and $63 \cdot 1 \mathrm{~mol} \%$, respectively; and values for strains LMG 21507 ${ }^{\mathrm{T}}$, LMG 21999, LMG 22000, LMG 22001 and LMG 22002 of rep-PCR cluster III are 60.4, 60.3, $59 \cdot 7,60 \cdot 1$ and $59 \cdot 4 \mathrm{~mol} \%$, respectively. These values are consistent with the $\mathrm{G}+\mathrm{C}$ content of the Rhodobacter group, which ranges between $52 \cdot 1$ and $65 \mathrm{~mol} \%$ (Labrenz et al., 2000; Urbance et al., 2001; Wagner-Döbler et al., 2003; González et al., 2003).

Cellular fatty acid patterns of the Antarctic strains are based on the data generated by Van Trappen et al. (2002). The strains showed similar fatty acid profiles (see Table 2 ), with the most abundant fatty acid being $18: 1 \omega 7 c$, accounting for $74 \cdot 1-87 \cdot 7 \%$ of the total fatty acids. This profile is 
Table 2. Fatty acid composition of the three species of the genus Loktanella

The mean percentages of total fatty acids with the corresponding standard deviations are given. ND, Not detected; $\mathrm{Tr}$, trace amount $(<1 \%$ of total). Summed feature 2 comprises any combination of 12:0 aldehyde, unknown 10.928, 16:1 iso I and 14:0 3OH. Summed feature 3 comprises 15:0 iso $2 \mathrm{OH}$ or 16:1 $\omega 7 c$ or both. Summed feature 7 comprises any combination of unknown 18.846, $19: 1 \omega 6 c$ and 19:0 cyclo $\omega 10 c$. Unknown fatty acids are designated by their equivalent chain lengths, relative to the chain lengths of known straight-chain saturated fatty acids.

\begin{tabular}{|lccc|}
\hline Fatty acid & $\begin{array}{c}\text { L. salsilacus } \\
(\mathbf{1 0} \text { strains })\end{array}$ & $\begin{array}{c}\text { L. fryxellensis } \\
(\mathbf{1 2} \text { strains })\end{array}$ & $\begin{array}{c}\text { L. vestfoldensis } \\
(\mathbf{4} \text { strains })\end{array}$ \\
\hline $10: 03 \mathrm{OH}$ & $2 \cdot 4 \pm 0 \cdot 7$ & $3 \cdot 7 \pm 1 \cdot 1$ & $6 \cdot 1 \pm 1 \cdot 5$ \\
$12: 13 \mathrm{OH}$ & $\mathrm{ND}$ & $\mathrm{ND}$ & $5 \cdot 6 \pm 1 \cdot 4$ \\
$16: 0$ & $2 \cdot 9 \pm 0 \cdot 9$ & $2 \cdot 7 \pm 1 \cdot 1$ & $2 \cdot 9 \pm 0 \cdot 7$ \\
$18: 0$ & $1 \cdot 4 \pm 0 \cdot 8$ & $1 \cdot 6 \pm 0 \cdot 9$ & $1 \cdot 8 \pm 0 \cdot 3$ \\
$18: 1 \omega 7 c$ & $87 \cdot 7 \pm 1 \cdot 9$ & $84 \cdot 9 \pm 3 \cdot 7$ & $74 \cdot 1 \pm 3 \cdot 1$ \\
$18: 1 \omega 7 c$ 11 Methyl & $\mathrm{Tr}$ & $\mathrm{ND}$ & $1 \cdot 9 \pm 0 \cdot 8$ \\
Summed feature 2 & $\mathrm{Tr}$ & $1 \cdot 7 \pm 0 \cdot 7$ & $\mathrm{ND}$ \\
Summed feature 3 & $2 \cdot 8 \pm 0 \cdot 9$ & $\mathrm{ND}$ & $\mathrm{ND}$ \\
Summed feature 7 & $1 \cdot 2 \pm 1 \cdot 0$ & $4 \cdot 7 \pm 2 \cdot 0$ & $4 \cdot 7 \pm 0 \cdot 7$ \\
Unknown 11.799 & $\mathrm{ND}$ & $\mathrm{ND}$ & $2 \cdot 3 \pm 1 \cdot 2$ \\
\hline
\end{tabular}

characteristic for several major phylogenetic groups of the $\alpha$-Proteobacteria. Other fatty acids, in lower proportions, are $10: 03 \mathrm{OH}, 16: 0,18: 0$ and summed feature 7 (comprising the unknown fatty acid 18.846, 19:1 $1 \omega 6 \mathrm{c}$ and 19:0 cyclo $\omega 10 c)$. The Antarctic strains can be differentiated from phylogenetic neighbour $J$. helgolandensis by the relative amount of $18: 1 \omega 7 c(45-52 \%)$ and 19:0 cyclo (20-25\%) and from Ketogulonicigenium species by the relative amount of 16:0 (32-39\%) and 18:1 $\omega 7 c(41-55 \%)$. The strains belonging to the different rep-PCR clusters can be differentiated from each other by the presence or absence of, for example, summed feature 2 (comprising any combination of $12: 0$ aldehyde, unknown $10.928,16: 1$ iso I and 14:0 3OH), 18:1 $\omega 7 c 11$ methyl and the unknown fatty acid 11.799 .

The following morphological, physiological and biochemical tests were performed. The strains were aerobic and chemoheterotrophic, and there was no growth under anaerobic conditions. Growth at different temperatures $\left(5-45^{\circ} \mathrm{C}\right)$ was tested on marine agar, and salt tolerance on R2A agar (composition per litre: $0.5 \mathrm{~g}$ yeast extract, $0.5 \mathrm{~g}$ proteose peptone No.3, $0.5 \mathrm{~g}$ Casamino acids, $0.5 \mathrm{~g}$ glucose, $0.5 \mathrm{~g}$ soluble starch, $0.3 \mathrm{~g}$ sodium pyruvate, $0.3 \mathrm{~g}$ dipotassium phosphate, $0.05 \mathrm{~g}$ magnesium sulfate, $15.0 \mathrm{~g}$ agar), supplemented with $1-20 \% \mathrm{NaCl}$ at $25^{\circ} \mathrm{C}$. The strains of repPCR cluster III and rep-PCR cluster I were able to grow at $5-30{ }^{\circ} \mathrm{C}$ and $5-25^{\circ} \mathrm{C}$, respectively, whereas the strains of repPCR cluster II tolerated temperatures up to $37^{\circ} \mathrm{C}$. No growth occurred at $40{ }^{\circ} \mathrm{C}$. Growth appeared on R2A agar with up to $10 \% \mathrm{NaCl}$ for the strains of rep-PCR cluster III and rep-PCR cluster II, whereas the strains of rep-PCR cluster I only grew with up to $5 \% \mathrm{NaCl}$.

Colony morphology was determined on marine agar after
7 days. In addition, growth and adherence of colonies on $\mathrm{R} 2 \mathrm{~A}$, nutrient and trypticase/soy agars were tested. Cells were tested for their reaction to the Gram stain and for catalase and oxidase activity. Tests in the commercial systems API ZYM, API 20NE and API 20E (bioMérieux) were generally performed according to the manufacturer's instructions. The API ZYM tests were read after $4 \mathrm{~h}$ incubation at $25^{\circ} \mathrm{C}$, the other API tests after $48 \mathrm{~h}$ at $25^{\circ} \mathrm{C}$. Degradation of casein (Reichenbach \& Dworkin, 1981), DNA (using DNA agar from Difco, supplemented with $0.01 \%$ toluidine blue from Merck), starch, Tween 80 and L-tyrosine (Barrow \& Feltham, 1993) was tested and reactions were read after 5 days.

The strains show the typical morphological characteristics of the Rhodobacter group (Labrenz et al., 2000; Urbance et al., 2001; Wagner-Döbler et al., 2003; González et al., 2003) and their physiological and biochemical characteristics are given in the descriptions below. The strains of rep-PCR clusters I, II and III can be differentiated from each other and related genera by several phenotypic characteristics (see Table 3 and Table 4).

On the basis of these results, a new genus with the name Loktanella gen. nov. is proposed with three species, Loktanella salsilacus sp. nov. (rep-PCR cluster III, type species), Loktanella fryxellensis sp. nov. (rep-PCR cluster I) and Loktanella vestfoldensis sp. nov. (rep-PCR cluster II).

\section{Description of Loktanella gen. nov.}

Loktanella (Lok.tan.el'la. N.L. fem. n. Loktanella named after Tjhing-Lok Tan from the Alfred Wegener Institute in Bremerhaven, who contributed to our understanding of marine and polar bacteriology and ecology). 
Table 3. Phenotypic characteristics that differentiate the three species of the genus Loktanella

- , Negative; + , positive; $(+)$, weakly positive.

\begin{tabular}{|lccc|}
\hline Characteristic & L. salsilacus & L. fryxellensis & L. vestfoldensis \\
\hline Pigmentation & Beige & Pink-beige & Pink \\
Growth on: & - & - & $(+)$ \\
$\quad$ Trypticase/soy agar & - & - & $(+)$ \\
$\quad$ Nutrient agar & $0-10$ & $0-5$ & $0-10$ \\
Salinity range $(\% \mathrm{NaCl})$ & $5-30$ & $5-25$ & $5-37$ \\
Temperature range $\left({ }^{\circ} \mathrm{C}\right)$ & - & - & + \\
Hydrolysis of urea & - & - & + \\
Production of: & + & - & - \\
$\quad$ Trypsin & $59 \cdot 4-60 \cdot 4$ & $65 \cdot 7-66 \cdot 4$ & $62 \cdot 1-63 \cdot 1$ \\
$\quad \alpha-$ Galactosidase & & & \\
G + C content $(\mathrm{mol} \%)$ & &
\end{tabular}

Gram-negative, rod-shaped cells that are strictly aerobic, moderately halotolerant and chemoheterotrophic. They do not form spores and the optimal growth temperature is $25{ }^{\circ} \mathrm{C}$. Motility is not observed. Cytochrome oxidase-, catalase- and $\beta$-galactosidase-positive. The dominant fatty acid is $18: 1 \omega 7 c$ and other characteristic fatty acids are $10: 0$ $3 \mathrm{OH}, 16: 0,18: 0$ and summed feature 7 (which comprises the unknown fatty acid 18.846, 19:1 $\omega 6 \mathrm{c}$ and 19:0 cyclo $\omega 10 c)$. The DNA $\mathrm{G}+\mathrm{C}$ content ranges from $59 \cdot 4$ to $66.4 \mathrm{~mol} \%$. As determined by $16 \mathrm{~S}$ rRNA gene sequence analysis, the genus Loktanella belongs to the Rhodobacter group within the $\alpha$-Proteobacteria.
The type species is Loktanella salsilacus.

Description of Loktanella salsilacus sp. nov.

Loktanella salsilacus (sal.si.la'cus. L. adj. salsus salt, salty; L. gen. n. lacus of a lake; N.L. gen. n. salsilacus of a salt lake, referring to the isolation source, Ace Lake and Organic Lake, Vestfold Hills, Antarctica).

Cells are Gram-negative, short rods ( $<1 \mu \mathrm{m}$ by $3-4 \mu \mathrm{m})$, often forming pairs or short chains. Strains grow at $5-30{ }^{\circ} \mathrm{C}$; weak growth is observed at $37^{\circ} \mathrm{C}$ and no growth occurs at $45^{\circ} \mathrm{C}$. Beige, convex, translucent colonies with a diameter

Table 4. Phenotypic characteristics that differentiate Loktanella from other related members of the 'Rhodobacteraceae'

Genus: 1, Loktanella; 2, Ketogulonicigenium; 3, Jannaschia; 4, Octadecabacter; 5, Antarctobacter, 6, Sulfitobacter; 7, Roseobacter. Data for Ketogulonicigenium, Jannaschia, Octadecabacter, Antarctobacter, Sulfitobacter and Roseobacter are from the literature (Urbance et al., 2001; Wagner-Döbler et al., 2003; Gosink et al., 1997; Labrenz et al., 1998, 1999, 2000; Pukall et al., 1999; Shiba, 1991; Lafay et al., 1995; Ruiz-Ponte et al., 1998). -, Negative; +, positive; v, variable results; ND, not determined.

\begin{tabular}{|lccccccc|}
\hline Characteristic & $\mathbf{1}$ & $\mathbf{2}$ & $\mathbf{3}$ & $\mathbf{4}$ & $\mathbf{5}$ & $\mathbf{6}$ & $\mathbf{7}$ \\
\hline Rosettes formed & - & - & - & - & + & + & V \\
Colony colour & Pink-beige & Brown & White & White & Brown-yellow & V & V \\
Motility & - & + & - & - & $+/-$ & + & + \\
Optimum temperature $\left({ }^{\circ} \mathrm{C}\right)$ & 25 & $25-31$ & $25-30$ & $4-15$ & $16-26$ & $17-28$ & $20-30$ \\
Oxidase & + & + & $(+)$ & - & + & + & + \\
Carbon utilization & - & + & + & + & + & + & + \\
Hydrolysis of: & & & & & & & \\
$\quad$ Aesculin & + & ND & - & ND & ND & ND & + \\
Gelatin & - & ND & - & - & + & - & + \\
$\quad$ DNA & - & ND & ND & ND & + & - & ND \\
Tween 80 & + & ND & - & ND & - & + & ND \\
Nitrate reduction & - & ND & - & - & + & - & V \\
G + C content (mol\%) & $59-66$ & $52-54$ & 63 & $56-57$ & 62 & $57-63$ & $56-60$ \\
\hline
\end{tabular}


of 1-2 mm, with entire margins are formed on marine agar plates. Growth also occurs on R2A, but no growth is observed on trypticase/soy agar and nutrient agar. Colonies do not adhere to the agar. Degrades aesculin, Tween 80 and citrate. Growth on carbohydrates (API 20NE) is not observed and acids from carbohydrates are not produced (API 20E). Agar, casein, DNA, gelatin, starch, tyrosine and urea are not degraded. Tests for indole production, nitrate reduction, the Voges-Proskauer reaction and hydrogen sulfide production are negative. None of the strains shows activity for the enzymes arginine dihydrolase, lysine decarboxylase, ornithine decarboxylase, tryptophan deaminase (API 20E) and lipase $\left(\mathrm{C}_{14}\right)$, valine arylamidase, cystine arylamidase, $\alpha$-chymotrypsin, trypsin, $\beta$-galactosidase, $\beta$ glucuronidase, $N$-acetyl- $\beta$-glucosaminidase, $\alpha$-mannosidase and $\alpha$-fucosidase (API ZYM). Weak enzymic activity is observed for alkaline phosphatase, acid phosphatase, naphthol-AS-BI-phosphohydrolase, $\alpha$-glucosidase and $\beta$-glucosidase, medium activity for esterase $\left(\mathrm{C}_{4}\right)$, esterase lipase $\left(\mathrm{C}_{8}\right)$ and leucine arylamidase, and strong activity for $\alpha$-galactosidase (API ZYM). Growth occurs in $0-5 \% \mathrm{NaCl}$, with weak growth in $10 \% \mathrm{NaCl}$. The $\mathrm{G}+\mathrm{C}$ content of the strains is $59 \cdot 4-60 \cdot 4 \mathrm{~mol} \%$. Isolated from microbial mats from lakes Ace and Organic in the Vestfold Hills, Antarctica.

The type strain is LMG $21507^{\mathrm{T}}\left(=\mathrm{CIP} 108322^{\mathrm{T}}\right)$.

\section{Description of Loktanella fryxellensis sp. nov.}

Loktanella fryxellensis (fry.xell.en'sis N.L. fem. adj. fryxellensis referring to the isolation source, Lake Fryxell, Antarctica).

Cells are Gram-negative, short rods $(<1 \mu \mathrm{m}$ by $2-3 \mu \mathrm{m})$, often forming pairs or short chains. Strains grow at $5-25^{\circ} \mathrm{C}$; optimal growth temperature is $25^{\circ} \mathrm{C}$ but weak growth occurs at $30^{\circ} \mathrm{C}$. Pale-pink to beige, convex, translucent colonies with a diameter of $1 \mathrm{~mm}$, with entire margins formed on marine agar plates after 6 days incubation. Growth also occurs on R2A agar, but the strains do not grow on nutrient agar or trypticase/soy agar, and colonies do not adhere to the agar. Degrades aesculin, Tween 80 and citrate (weak reaction). No growth is observed (API 20NE) on carbohydrates and acids are not produced from carbohydrates (API 20E). Agar, casein, DNA, gelatin, tyrosine and urea are not degraded. Tests for indole production, nitrate reduction, the Voges-Proskauer reaction and hydrogen sulfide production are negative. None of the strains shows activity for the enzymes arginine dihydrolase, lysine decarboxylase, ornithine decarboxylase, tryptophan deaminase (API 20E) and lipase $\left(C_{14}\right)$, cystine arylamidase, $\alpha$-chymotrypsin, trypsin, $\alpha$-galactosidase, $\beta$ glucuronidase, $N$-acetyl- $\beta$-glucosaminidase, $\alpha$-mannosidase and $\alpha$-fucosidase (API ZYM). Weak enzymic activity is observed for valine arylamidase, acid phosphatase, naphthol-AS-BI-phosphohydrolase and $\alpha$-glucosidase, medium activity for alkaline phosphatase, esterase $\left(\mathrm{C}_{4}\right)$, esterase lipase $\left(\mathrm{C}_{8}\right), \beta$-galactosidase and leucine arylamidase, and strong activity for $\beta$-glucosidase (API ZYM). Growth occurs in $0-5 \% \mathrm{NaCl}$ but not in $10 \% \mathrm{NaCl}$. The $\mathrm{G}+\mathrm{C}$ content of the strains is $65 \cdot 7-66 \cdot 4 \mathrm{~mol} \%$. Isolated from microbial mats from Lake Fryxell, in the McMurdo Dry Valleys, Antarctica.

The type strain is LMG $22007^{\mathrm{T}}\left(=\mathrm{CIP} 108323^{\mathrm{T}}\right)$.

\section{Description of Loktanella vestfoldensis sp. nov.}

Loktanella vestfoldensis (vest.fold.en'sis. N.L. fem. adj. vestfoldensis referring to the isolation source, lakes Ace and Pendant, Vestfold Hills, Antarctica).

Cells are Gram-negative, short rods $(<1 \mu \mathrm{m}$ by $3-4 \mu \mathrm{m})$, often forming pairs or short chains. Strains grow at $5-37^{\circ} \mathrm{C}$, but no growth is observed at $45^{\circ} \mathrm{C}$. Pale-pink, convex, translucent colonies with a diameter of $<1 \mathrm{~mm}$, with entire margins formed on marine agar plates. Growth also occurs on trypticase/soy agar (weak growth), nutrient agar (weak growth) and R2A agar. Colonies do not adhere to the agar. Degrades aesculin, Tween 80, citrate and urea. No growth is observed (API 20NE) on carbohydrates and acids are not produced from carbohydrates (API 20E). Agar, casein, DNA, gelatin, tyrosine and starch are not degraded. Tests for indole production, nitrate reduction, hydrogen sulfide production and the Voges-Proskauer reaction are negative. None of the strains shows activity for the enzymes arginine dihydrolase, lysine decarboxylase, ornithine decarboxylase, tryptophan deaminase (API 20E) and lipase $\left(\mathrm{C}_{14}\right)$, valine arylamidase, cystine arylamidase, $\alpha$-chymotrypsin, $\alpha$-galactosidase, $\beta$-glucuronidase, $N$-acetyl- $\beta$ glucosaminidase, $\alpha$-mannosidase and $\alpha$-fucosidase (API ZYM). Weak enzymic activity is observed for alkaline phosphatase, leucine arylamidase, naphthol-AS-BIphosphohydrolase, $\beta$-galactosidase, $\alpha$-glucosidase and $\beta$-glucosidase, medium activity for esterase $\left(\mathrm{C}_{4}\right)$, esterase lipase $\left(\mathrm{C}_{8}\right)$ and acid phosphatase, and strong activity for trypsin (API ZYM). Growth occurs in $0-5 \% \mathrm{NaCl}$ and weak growth in $10 \% \mathrm{NaCl}$. The $\mathrm{G}+\mathrm{C}$ content of the strains is $62 \cdot 1-63 \cdot 1 \mathrm{~mol} \%$. Isolated from microbial mats from lakes Ace and Pendant in the Vestfold Hills, Antarctica.

The type strain is LMG $22003^{\mathrm{T}}\left(=\mathrm{CIP} 108321^{\mathrm{T}}\right)$.

\section{Acknowledgements}

This work was funded by the Bijzonder Onderzoeksfonds (BOF), Universiteit Gent, Belgium. Part of this work was conducted in the framework of the MICROMAT project 'Biodiversity of microbial mats in Antarctica' (project no. BIO4980040), funded by the European Commission under the Biotech Programme. J.S. acknowledges the Fund for Scientific Research FWO (Belgium). We are grateful to Dr J. P. Euzéby for his help with nomenclature.

\section{References}

Barrow, G. I. \& Feltham, R. K. A. (1993). Cowan and Steel's Manual for the Identification of Medical Bacteria, 3rd edn. Cambridge: Cambridge University Press. 
Ezaki, T., Hashimoto, Y. \& Yabuuchi, E. (1989). Fluorometric deoxyribonucleic acid-deoxyribonucleic acid hybridization in microdilution wells as an alternative to membrane filter hybridization in which radioisotopes are used to determine genetic relatedness among bacterial strains. Int J Syst Bacteriol 39, 224-229.

González, J. M., Kiene, R. P. \& Moran, M. A. (1999). Transformation of sulfur compounds by an abundant lineage of marine bacteria in the alpha-subclass of the class Proteobacteria. Appl Environ Microbiol 65, 3810-3819.

González, J. M., Simo, R., Massana, R., Covert, J. S., Casamayor, E. O., Pedros-Alio, C. \& Moran, M. A. (2000). Bacterial community structure associated with a dimethylsulfoniopropionate-producing North Atlantic algal bloom. Appl Environ Microbiol 66, 4237-4246.

González, J. M., Covert, J. S., Whitman, W. B. \& 8 other authors (2003). Silicibacter pomeroyi sp. nov. and Roseovarius nubinhibens sp. nov., dimethylsulfonioproprionate-demethylating bacteria from marine environments. Int J Syst Evol Microbiol 53, 1261-1269.

Gosink, J. J., Herwig, R. P. \& Staley, J. T. (1997). Octadecabacter arcticus gen. nov., sp. nov., and $O$. antarcticus sp. nov., nonpigmented, psychrophilic gas vacuolate bacteria from polar sea ice and water. Syst Appl Microbiol 20, 356-365.

Hall, T. A. (1999). BIOEDIT: a user-friendly biological sequence alignment editor and analysis program for Windows 95/98/NT. Nucleic Acids Symp Ser 41, 95-98.

Labrenz, M., Collins, M. D., Lawson, P. A., Tindall, B. J., Braker, G. \& Hirsch, P. (1998). Antarctobacter heliothermus gen. nov., sp. nov., a budding bacterium from hypersaline and heliothermal Ekho lake. Int J Syst Bacteriol 48, 1363-1372.

Labrenz, M., Collins, M. D., Lawson, P. A., Tindall, B. J., Schumann, P. \& Hirsch, P. (1999). Roseovarius tolerans gen. nov., sp. nov., a budding bacterium with variable bacteriochlorophyll $a$ production from hypersaline Ekho lake. Int J Syst Bacteriol 49, 137-147.

Labrenz, M., Tindall, B. J., Lawson, P. A., Collins, M. D., Schumann, P. \& Hirsch, P. (2000). Staleya guttiformis gen. nov., sp. nov. and Sulfitobacter brevis sp. nov., $\alpha$-3-Proteobacteria from hypersaline, heliothermal and meromictic antarctic Ekho lake. Int J Syst Evol Microbiol 50, 303-313.

Lafay, B., Ruimy, R., Rausch de Traubenberg, C., Breittmayer, V., Gauthier, M. J. \& Christen, R. (1995). Roseobacter algicola sp. nov., a new marine bacterium isolated from the phycosphere of the toxin-producing dinoflagellate Prorocentrum lima. Int J Syst Bacteriol 45, 290-296.

Marmur, J. (1961). A procedure for the isolation of deoxyribonucleic acid from micro-organisms. J Mol Biol 3, 208-218.

Pitcher, D. G., Saunders, N. A. \& Owen, R. J. (1989). Rapid extraction of bacterial genomic DNA with guanidinium thiocyanate. Lett Appl Microbiol 8, 151-156.

Pukall, R., Buntefuß, D., Frühling, A., Rohde, M., Kroppenstedt, R. M., Burghardt, J., Lebaron, P., Bernard, L. \& Stackebrandt, E. (1999). Sulfitobacter mediterraneus sp. nov., a new sulfite-oxidizing member of the $\alpha$-Proteobacteria. Int J Syst Bacteriol 49, 513-519.

Rademaker, J. L. W. \& de Bruijn, F. J. (1997). Characterization and classification of microbes by rep-PCR genomic fingerprinting and computer assisted pattern analysis. In DNA Markers: Protocols, Applications and Overviews, pp. 151-171. Edited by G. CaetanoAnollés \& P. M. Gresshoff. New York: Wiley.

Rademaker, J. L. W., Hoste, B., Louws, F. J., Kersters, K., Swings, J., Vauterin, L., Vauterin, P. \& de Bruijn, F. J. (2000). Comparison of
AFLP and rep-PCR genomic fingerprinting with DNA-DNA homology studies: Xanthomonas as a model system. Int J Syst Evol Microbiol 50, 665-677.

Raes, J. \& Van de Peer, Y. (1999). ForCon: a software tool for the conversion of sequence alignments. http://www.ebi.ac.uk/embnet.news/ vol6_1/ForCon/body_forcon.html.

Reichenbach, H. \& Dworkin, M. (1981). Introduction to the gliding bacteria. In The Prokaryotes, vol. 1, pp. 315-327. Edited by M. P. Starr, H. Stolp, H. G. Trüper, A. Balows \& H. G. Schlegel. Berlin: Springer.

Ruiz-Ponte, C., Cilia, V., Lambert, C. \& Nicolas, J. L. (1998). Roseobacter gallaeciensis sp. nov., a new marine bacterium isolated from rearings and collectors of the scallop Pecten maximus. Int J Syst Bacteriol 48, 537-542.

Saitou, N. \& Nei, M. (1987). The neighbour-joining method: a new method for reconstructing phylogenetic trees. Mol Biol Evol 4, 406-425.

Shiba, T. (1991). Roseobacter litoralis gen. nov., sp. nov., and Roseobacter denitrificans sp. nov., aerobic pink-pigmented bacteria which contain bacteriochlorophyll a. Syst Appl Microbiol 14, 140145.

Urbance, J. W., Bratina, B. J., Stoddard, S. F. \& Schmidt, T. M. (2001). Taxonomic characterization of Ketogulonigenium vulgare gen. nov., sp. nov. and Ketogulonigenium robustum sp. nov., which oxidize L-sorbose to 2-keto-L-gulonic acid. Int J Syst Evol Microbiol 51, 1059-1070.

Van de Peer, Y. \& De Wachter, R. (1994). TREECON for Windows: a software package for the construction and drawing of evolutionary trees for the Microsoft Windows environment. Comput Appl Biosci 10, 569-570.

Van Trappen, S., Mergaert, J., Van Eygen, S., Dawyndt, P., Cnockaert, M. C. \& Swings, J. (2002). Diversity of 746 heterotrophic bacteria isolated from microbial mats from ten Antarctic lakes. Syst Appl Microbiol 25, 603-610.

Van Trappen, S., Mergaert, J. \& Swings, J. (2003). Flavobacterium gelidilacus sp. nov., isolated from microbial mats in Antarctic lakes. Int J Syst Evol Microbiol 53, 1241-1245.

Van Trappen, S., Vandecandelaere, I., Mergaert, J. \& Swings, J. (2004). Flavobacterium degerlachei sp. nov., Flavobacterium frigoris sp. nov. and Flavobacterium micromati sp. nov., novel psychrophilic bacteria isolated from microbial mats in Antarctic lakes. Int J Syst Evol Microbiol 54, 85-92.

Versalovic, J., Koeuth, T. \& Lupski, J. R. (1991). Distribution of repetitive DNA sequences in eubacteria and application to fingerprinting in bacterial genomes. Nucleic Acids Res 19, 6823-6831.

Versalovic, J., Schneider, M., de Bruijn, F. J. \& Lupski, J. R. (1994). Genomic fingerprinting of bacteria using repetitive sequence-based polymerase chain reaction. Methods Mol Cell Biol 5, 25-40.

Wagner-Döbler, I., Rheims, H., Felske, A., Pukall, R. \& Tindall, B. J. (2003). Jannaschia helgolandensis gen. nov., sp. nov., a novel abundant member of the marine Roseobacter clade from the North Sea. Int J Syst Evol Microbiol 53, 731-738.

Wayne, L. G., Brenner, D. J., Colwell, R. R. \& 9 other authors (1987). International Committee on Systematic Bacteriology. Report of the ad hoc committee on reconciliation of approaches to bacterial systematics. Int J Syst Bacteriol 37, 463-464. 